\title{
УДК 711.4
}

\section{FUNCTIONAL ORGANIZATION OF FUNCTIONAL SUPPLEMENTAL SPACES}

\section{ФУНКЦІОНАЛЬНА ОРГАНІЗАЦІЯ СУЧАСНИХ СУСПІЛЬНИХ ПРОСТОРІВ}

Zhabina A.I./Жабіна A.I. acnipaнm/postgraduate

\author{
Beketov national University of urban economy, Kharkiv, Revolutsii Street, 12, 61002 \\ Харківський національний університет міського господарства імені О.М. Бекетова, \\ Харків,вул. Революиї, 12, 61002 \\ http://orcid.org/0000-0000-0000-0000
}

\begin{abstract}
Анотація. У роботі розглянута проблема функиіональної організації сучасних суспільних просторів у зонах транспортно-комунікаційних вузлів міста, на прикладі м.Харкова. Зроблено висновок про важливу роль комунікативних просторів для гуманізаиіі міського середовища $i$ необхідності вдосконалення $\ddot{x}$ функиіонально-планувальноі організації в зонах транспортно-комунікаційних вузлів.
\end{abstract}

Ключеві слова: суспільні простори, транспортно-комунікачійні вузли міста, гуманізація, функціонально-планувальна організація.

Різноманіття процесів життєдіяльності, що відбуваються в місті, знаходить своє відображення в особливостях матеріальних форм його функціональнопросторових складових. У найбільш загальному вигляді в структурі кожного поселення можна виділити зони виробничої, побутової, рекреаційної та комунікаційної діяльності, які мають виразну специфіку їх містобудівної організації. Ці зони охоплюють територію усього міста і фіксуються в схемах його функціонального зонування, a їх побудова має фіксовані регламенти в державних нормативних документах [6].

Однак сьогодні при формування міського простору усе більша увага приділяється відносно невеликим (від 0,1 до 2-х га) ділянкам, які, на думку багатьох фахівців, забезпечують процеси, що втілюють саму сутність феномену «місто». Тут локалізуються процеси, що не пов’язані з працею, або побутом, тобто знаходяться за межами функціонально-утилітарних потреб. Це так звані «треті міста» або публічні (суспільні) простори. Їх присутність можна виявити майже усюди: і серед житлової забудови і в міському центрі, і в транспортнокомунікаційному вузлу i поруч 3 виробничим підприємством. Велика зацікавленість в їх формуванні, вдосконаленні, розвитку породжує різноманіття підходів до вирішення проблеми архітектурно-містобудівної організації даних територій, а також визначення їх основних функціональних характеристик.

Метою даної роботи с побудова узагальненої функціональної моделі суспільного простору на основі систематизації його актуальних визначень, що склалися в різних наукових сферах. Така модель сприятиме відповіді на питання: «Які функції повинні виконувати суспільні простори щоб задовільнити потреби мешканців міста?». Актуальність теми обумовлена загальною світовою тенденцією пошуку шляхів гуманізації міського простору, його вдосконалення для задовільнення потреб міської громади, людини.

Методика дослідження включає аналіз і систематизацію даних наукових 
робіт термінологічний аналіз, натурні дослідження, в тому числі фотофіксацію. До роботи залучені результати досліджень суспільних просторів в м.Харкові.

\section{Аналіз останніх досліджень і публікацій.}

Аналіз наукового досвіду за темою даного дослідження проводився у напрямках вивчення наукових робіт з таких наукових сфер як архітектура, містобудування, дизайн міського середовища, соціологія, урбаністика. Так, соціально-функціональні аспекти формування суспільних міських просторів розглянуто в роботах таких авторів як: Т. Баталина, Я.Гейл, В. Глазичев, Б. Гройс, С.Серикжанова та ін. $[1,3-5,12]$. Так, Я.Гейл у своїй відомій роботі зауважив, що живому місту необхідне різноманітне і складне міське життя: рекреаційна та соціальна активність повинна в ньому сполучатися 3 простором для пішохідного руху, а також можливістю приймати участь в міському житті [3]. Дослідники солідарні у висновках, що суспільні простори грають важливу роль в процесах життєдіяльності городян, формують їх самосвідомість, створюють ідентичність та унікальність міських територій [3, 7-11]. Перспективи потенціального розвитку суспільних просторів, їх можливості задовольняти потреби мешканців розглянуто в роботі [14]. Автори наголошують, що суспільні простори стимулюють активність людей, дозволяють їм відчути себе частиною суспільства.

\section{Основна частина.}

Один із напрямків розвитку урбанізованого простору - це перехід від простих функціонально-утилітарних схем його організації до багатофункціональних утворень, які втілюють динамічність, багатогранність та багатоаспектність міського життя. Саме такі якості притаманні суспільним міським просторам. Під суспільними просторами, науковці розуміють частину міського середовища, створюваного в інтересах городян і гостей міста для вільного самовираження, неформальних комунікацій, відпочинку та прояву своїх здібностей на благо суспільства [1, 3-6]. Їх важливість для міста потребує уважного та системного вивчення функціональних властивостей і просторових характеристик даних територій.

Важливим кроком у дослідженні «суспільних просторів», як особливого феномену міського життя та специфічного територіального об'єкту, $\epsilon$ визначення їх місця в загальній системі відкритих міських просторів. До останніх науковці відносять: озеленені простори загального користування (сади, парки, сквери набережні, бульвари); пішохідні частини вулиць, міських магістралей, площі; аван-площадки перед громадськими будівлями, інші громадські території (рис 1).

Натурні дослідження виявили, що суспільні простори не завжди формуються в структурі вище перелічених ділянок. Не рідка можна побачити в місті сквери, бульвари, вулиці, в яких не спостерігається соціальної активності мешканців. У низці наукових робіт наголошено, що ефективність міських просторів знижується із-за невідповідності їх функціонального наповнення потребам людей та незадовільного стану благоустрою, що суттєво впливає на формування суспільних просторів [9,12]. 


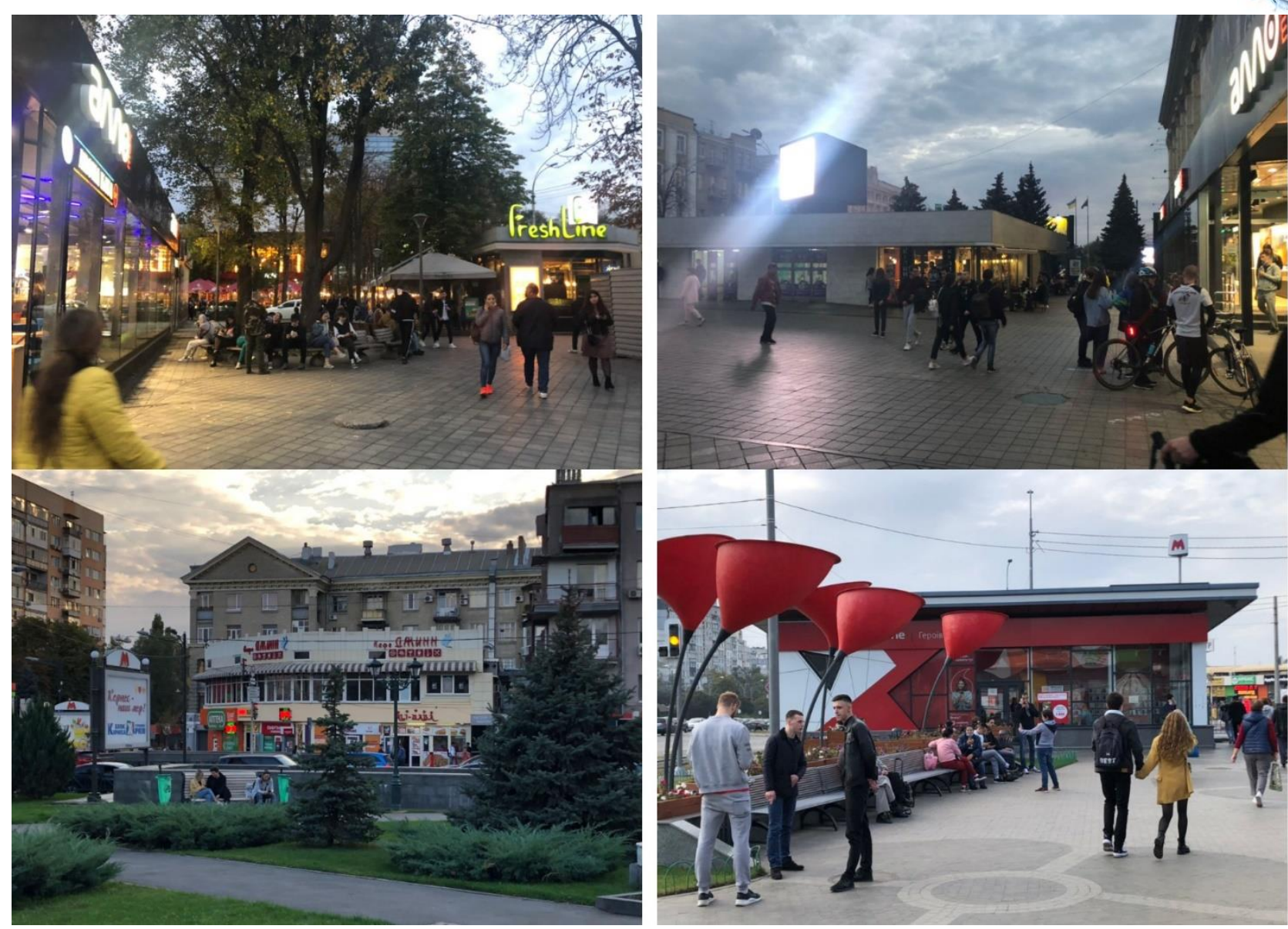

Рисунок 1

Однак, слід погодитись з іншими дослідниками міського середовища, які пов'язують виникнення та розвиток суспільних просторів 3 розвитком соціальних взаємодій в суспільстві, що «закріплюються» в міській тканині. Так в своїй роботі Л. Лофланд виділяє три типи "місць", або локусов: пам'ятні (фіксувальні моменти колективної пам'яті, як, наприклад, храм або публічний парк), знайомі місця/шляху/стежки та домашні території, або місця для тусовки (місця, де люди живуть і почувають себе "як вдома" [8]. Серед основних умов успішного функціонування публічного простору автор виділяє: зручність, приємний імідж, різноманітність використання простору і занять, задоволення від інтеграцій, спостереження за людьми, "карнавальность" - можливість гри, фестивалю, позбавлення від своєї істинної ідентичності, придбання нових масок. В роботі «Суспільний простір в сучасному розумінні» автор приходить до висновку, що в основі формування даних об'єктів повинно бути соціокультурне проектування, що дозволить їм не тільки виконувати функцію рекреації або вирішувати іміджеві завдання, але $\ddot{i}$ допомагати місцевим мешканцям розвиватися разом 3 цими об'єктами, знаходити новий сенс і бачити перспективи в рідному місті " [10]. Парк, площа, тротуар, відкритий ринок, на думку вчених, здатні зробити значно більше, чим здається, пропонуючи нескінченні сюрпризи. Комерційні підприємства і місця споживання, відпочинку і веселощів, місця, де люди ходять, сидять, збираються, розмовляють, продають, існують - це місця для людей [14 ]. Важливої для даної роботи є дослідження Г.Ревзіна. Він характеризує суспільний простір як місце, що концентрує в 
собі різноманітні потоки i яке може бути конкурентоздатним. Автор наголошує, що громадські простри - це місця ще не визначеної, не сформованої повністю (не дозрілої) функції, своєрідний інкубатор майбутнього розвитку.

Підсумовуючи, можна наголосити, що суспільні простори це особливі міські території, де існують містобудівні умови вільного розгортання процесів самодіяльності городян, побудованих на різноманітних соціальних взаємодіях.

Найбільш характерні серед них такі: покупець - продавець; спостерігач актор; слухач - промовець. Тому основними функціональними складовими суспільних просторів $€$ :

- елементи дрібної вуличної торгівлі, які розташовуються вздовж пішохідних шляхів;

- елементи швидкого харчування, які розміщуються суміжно;

- відкриті площадки, де часто розміщуються вуличні актори, музиканти, агітатори;

- куточки спокійного відпочинку, де можна неформально спілкуватись, або спостерігати за вуличним життям.

В різних містобудівних ситуаціях вище перелічені функціональні складові можуть бути присутні в різних пропорціях (рис 2).

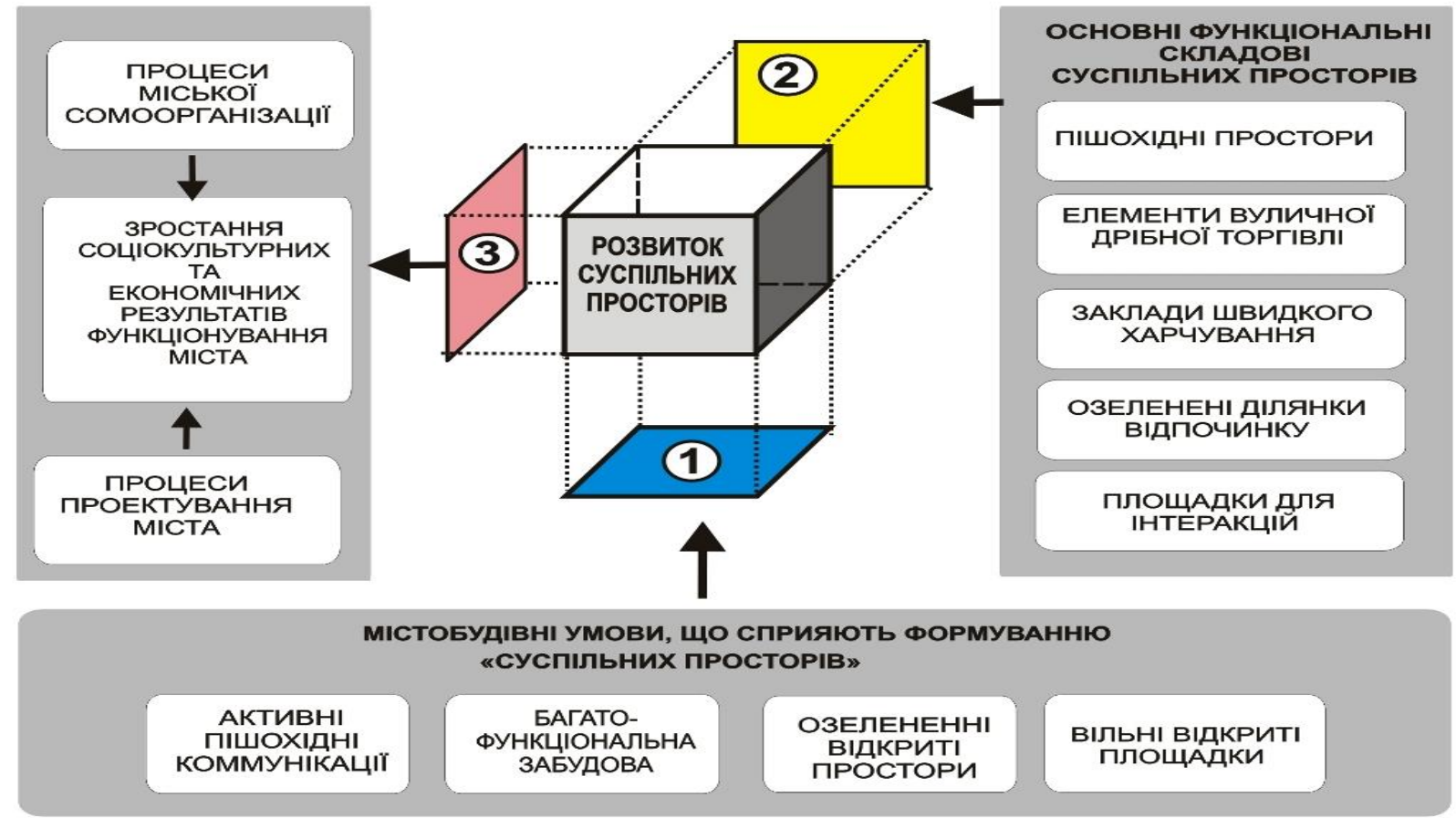

\section{Рис. 2. Логічна модель розвитку суспільних просторів сучасного міста}

Як показали натурні дослідження, виникнення та розвиток суспільних просторів в процесі міської самоорганізації відбувається в зонах активного пішохідного руху, а саме вздовж вулиць, що поєднують важливі об'єкти, в структурах транспортно-комунікаційних вузлів, суміжно 3 комплексами громадського обслуговування. Позитивний вплив на формування суспільних просторів має історична цінність забудови та іï функціональне різноманіття а також наявність елементів озеленення. [7, 11]. 


\section{Висновки.}

Систематизації актуальних визначень поняття «суспільного простору», що склалися в різних наукових сферах, показало, що існує два основних погляди на їх формування. Перший - пов'язує суспільні простори 3 упорядкованою організацію озеленених відкритих просторів загального користування, що створюються заздалегідь визначеними планами та нормативними вимогами. Такі простори в якості основних функцій мають різні форми відпочинку та прогулянок. Згідно другого погляду, суспільні простори - це, перш за все, динамічні територіальні утворення для вільного розвитку міської самодіяльної взаємодії.

Таким чином, основне функціональне призначення суспільних просторів $\epsilon$ забезпечення вільної, неформальної соціокультурної взаємодії мешканців міста, яка стає основою створення його привабливого іміджу, формування громадського суспільства. Основними функціональними складовими суспільних просторів є: пішохідні простори, елементи вуличної та дрібної торгівлі, харчування, озеленені ділянки спокійного відпочинку, площадки для різноманітних інтеракцій.

\section{Список літератури:}

1. Баталина Т.С. Анализ особенностей формирования общественного пространства // Бизнес и дизайн ревю. 2017. Т. 1. № 1(5). С. 11-15 [Электронный ресурс]. — Режим доступа:https://obe.ru/journal/2017 1/batalina-ts-analiz-osobennostej-formirovaniya-obshhestvennogo-prostranstva.

2. Гайкова Л.В. Потребительское зонирование при формировании городских общественных пространств. Академический вестник Уралниипроект РAACH №4, 2013. [Електроный ресурс]. — Режим доступу: https://cyberleninka.ru/article/n/potrebitelskoe-zonirovanie-pri-formirovaniigorodskih-obschestvennyh-prostranstv.

3. Гейл Я. Города для людей. Изд. На русском языке Концерн «КРОСТ», пер. с англ. М.: Альпина Паблишер, 2012. 276 с.

4. Глазычев. В.Л., Егоров М.М. и др. Городская среда. Технология развития: настольная книга. М.: Ладья, 1995. 240 с.

5. Гройс Б. Публичное пространство - от пустоты к парадоксу. URL: [Електроный ресурс]. — Режим доступа: https://strelka.com /category_ru/strelkapress-3/?lang=ru11].

6. ДБН Б.2.2.-12 : 2019 «Планування та забудова територий» [Електроный pecypc]. - Режим доступа: https://dreamdim.ua/wpcontent/uploads/2019/07/DBNB22-12-2019.pdf.

7. Dreval I.V Open spaces of Kharkov historical center and the problems of their architectural and urban planning transformation in modern conditions / International symposium «Environmental and engineering aspects for sustainable living» Hannover, 28 november, 2018. - c. 10-11. ISBN 978-3-00-032886-2.

8. Л.Лофланд. Доступно по ссылке:proceedings.usu.ru/7base $=\mathrm{mag} / 0035(01$ 09-2005) \&xsln=show Article.xslt\&id=a26\&doc =../content.jsp.

9. Лавров Л. П. Еремеева А. Ф. Городские общественные пространства - 
открытые и озелененные, их отличительные особенности // Современные общественные пространства как инструмент развития городской среды: материалы межрегион. науч.-практ. конф. 29-30 ноября 2018 года: СПбГАСУ. СПб., 2018. - 160 с. ISBN 978-5-9227-0878-4 https://www.spbgasu.ru/upload files/nauchinnovaz/konferenzii/20181122/\%D0\%A1\%D0\%BE\%D0\%B2\%D1\%80\% D0\%B5\%D0\%BC\%D0\%B5\%D0\%BD\%D0\%BD\%D1\%8B\%D0\%B5 \%D0\%BE\%D 0\%B1\%D1\%89\%D0\%B5\%D1\%81\%D1\%82\%D0\%B2\%D0\%B5\%D0\%BD\%D0\%B D\%D1\%8B\%D0\%B5 \%A1.pdf

10. Милевский Ю. Общественное пространство в современном понимании [Електроный ресурс]. — Режим доступу:

https://archsovet.msk.ru/opinions/obshhestvennoe-prostranstvo-v-sovremennomponimanii

11. Mazur T., Korol E. Public spaces development in urban block structure of the greater city historical center - evidence from lviv // s p a c e \& FORM przestrzeń i FORMa '36_2018. c.191-198

12. Малышева О.С. Щур О.А. Основные принципы формирования общественных пространств города // Современные общественные пространства как инструмент развития городской среды: материалы межрегион. науч.-практ. конф. 29-30 ноября 2018 года: СПбГАСУ. - СПб., 2018. - 160 с. ISBN 978-59227-0878-4 https://www.spbgasu.ru/upload files/nauchinnovaz/konferenzii/20181122/\%D0\%A1\%D0\%BE\%D0\%B2\%D1\%80\% D0\%B5\%D0\%BC\%D0\%B5\%D0\%BD\%D0\%BD\%D1\%8B\%D0\%B5 \%D0\%BE\%D 0\%B1\%D1\%89\%D0\%B5\%D1\%81\%D1\%82\%D0\%B2\%D0\%B5\%D0\%BD\%D0\%B D\%D1\%8B\%D0\%B5 \%A1.pdf

13. Серикжанова С.С. Публичное пространство в современном городе /Сборник материалов с конференции «Глобальные вызовы и современные тренды развития высшего образования». - Алматы, 2012 [Електронный ресурс]. - Режим доступу: https://articlekz.com/article/10959.

14. Hellberg, L and Johansson, Å, "Another Future for Thong Nhat Park, Public spaces in transition in the new urban reality of Hanoi." Master Thesis in Landscape Architecture, Swedish University of Agricultural Sciences, September 2008. http://exepsilon.slu.se/archive/00002957/01/

Another_future_for_Thong_Nhat_Park.pdf

Abstract. The paper considers the problem of functional organization of modern public spaces in the areas of transport and communication nodes of the city, on the example of Kharkiv. It is concluded that the important role of communication spaces for the humanization of the urban environment and the need to improve their functional and planning organization in the areas of transport and communication nodes.

Key words: public spaces, transport and communication nodes of the city, humanization, functional and planning organization. 